\title{
Implementasi Modul Berbasis Problem Based Learning dengan Metode SQ3R Materi Keanekaragaman Hayati untuk Meningkatkan Literasi Sains dan Sikap Peduli Lingkungan
}

\author{
Wahidah Qomariyah ${ }^{1}$, Mimien Henie Irawati Al Muhdhar ${ }^{1}$, Endang Suarsini ${ }^{1}$ \\ ${ }^{1}$ Pendidikan Biologi-Universitas Negeri Malang
}

\begin{tabular}{l}
\hline \hline INFO ARTIKEL \\
\hline Riwayat Artikel: \\
Diterima: 08-01-2019 \\
Disetujui: 17-03-2019 \\
\hline Kata kunci: \\
problem based learning; \\
SQ3R; \\
biodiversity; \\
scientific literacy; \\
environmental care attitude; \\
keanekaragaman hayati; \\
literasi sains; \\
sikap peduli lingkungan
\end{tabular}

Alamat Korespondensi:

Wahidah Qomariyah

Pendidikan Biologi

Universitas Negeri Malang

Jalan Semarang 5 Malang

E-mail: wahidahqomariyah22@gmail.com

\begin{abstract}
ABSTRAK
Abstract: This study aims to determine the implementation of PBL-based modules with the SQ3R Method (Survey, Question, Read, Recite, Review). The research method used was a quasi-experimental nonrandomized control group pretest-posttest design in class $\mathrm{X}$ IPA in Public High School 8 Kediri. The results of the study stated that the implementation of learning using PBL-based modules with the SQ3R method could increase the mean score of post-literacy science and environmental care attitude in the biodiversity material of class X IPA.
\end{abstract}

\begin{abstract}
Abstrak: Penelitian ini bertujuan untuk mengetahui implementasi modul berbasis Problem Based Learning dengan Metode SQ3R (Survey, Question, Read, Recite, Review). Metode penelitian yang digunakan adalah quasi eksperimen nonrandomized control group pretest-posttest design pada kelas X IPA di SMA Negeri 8 Kediri. Hasil penelitian menyatakan bahwa implementasi pembelajaran dengan menggunakan modul berbasis PBL dengan metode SQ3R dapat meningkatkan rerata nilai postes literasi sains dan sikap peduli lingkungan pada materi keanekaragaman hayati siswa kelas X IPA.
\end{abstract}

Literasi merupakan salah satu keterampilan pengukuran literasi membaca matematika dan sains oleh PISA (Programme for International student Assesment) pada tahun 2012 dan 2015 menunjukkan bahwa kemampuan siswa Indonesia masih dibawah rata-rata internasional, meskipun mengalami peningkatan (OECD Publishing, 2012, 2016). Dengan capaian tersebut, rata-rata kemampuan sains siswa Indonesia baru sampai pada kemampuan mengenali sejumlah fakta dasar, tetapi mereka belum mampu untuk mengomunikasikan dan mengaitkan kemampuan tersebut dengan berbagai topik sains, apalagi sampai menerapkan konsep-konsep (Thoharudin, Hendrawati, \& Rustaman, 2011). Perbandingan prestasi siswa Indonesia dalam PISA 2012 dan PISA 2015 dalam literasi sains mengalami kenaikan skor dari 382 menjadi 403, tetapi masih lebih rendah dari skor rata-rata internasional 493 (OECD Publishing, 2012, 2016). Literasi membaca mengalami kenaikan yang sangat sedikit dari 396 pada PISA 2012 menjadi 397 pada PISA 2015 dengan rata-rata skor internasional 493 (OECD Publishing, 2012, 2016) menunjukkan bahwa budaya membaca masih rendah dan tidak mengalami kemajuan yang berarti.

Berdasarkan hasil observasi yang dilaksanakan dengan menggunakan kuesioner dan wawancara terhadap siswa kelas X MIPA di SMA Negeri 8 Kediri didapatkan hasil bahwa secara umum siswa telah mengenal dan mengikuti pembelajaran kooperatif yang dilaksanakan oleh guru namun masih terkendala oleh kurangnya sarana laboratorium di sekolah. Siswa juga telah memiliki buku penunjang dari penerbit, tetapi belum terbiasa untuk membaca karena tidak ditugaskan oleh guru (22\%), hanya membaca sub pokok bahasan atau rangkuman pada saat diminta oleh guru (47\%), dan tidak tertarik untuk membaca (31\%). Pengetahuan siswa dalam literasi sains sangat terbatas, dimana hanya $31 \%$ siswa yang mengerti materi pembelajaran yang terkait indikator literasi sains, dan sebanyak $69 \%$ siswa menjawab tidak tahu. Berkaitan dengan permasalahan lingkungan siswa dapat mendefinisikan permasalahan lingkungan di sekolah $(68 \%)$ seperti kurangnya pengelolaan sampah, kurangnya pepohonan di lingkungan sekolah dan kondisi tanaman yang layu, namun hanya sebagian kecil siswa yang bersedia mengajukan solusi permasalahan tersebut $(10 \%)$.

Literasi sains didefinisikan sebagai pengetahuan dan pemahaman konsep dan proses ilmiah dalam pengambilan keputusan, berpartisipasi sebagai warga negara dan berperan dalam produktivitas ekonomi (NCREL and the Metiri Group, 2003) yang merujuk pada kompetensi untuk menjelaskan fenomena ilmiah, mengevaluasi dan merancang penyelidikan ilmiah serta menginterpretasikan data sebagai bukti ilmiah (OECD Publishing, 2016). Kompetensi tersebut dapat diintegrasikan dalam mata 
pelajaran sains sesuai dengan kompetensi dasar yang harus dicapai oleh siswa dalam kurikulum. Literasi sains pada siswa dapat ditingkatkan dengan penerapan model pembelajaran yang tepat, salah satunya yaitu dengan model pembelajaran PBL (Problem Based Learning) atau pembelajaran berbasis masalah (Suwono, Rizkita, \& Susilo, 2015). Model pembelajaran berbasis masalah adalah model pembelajaran dengan pendekatan pembelajaran siswa pada masalah autentik sehingga siswa dapat menyusun pengetahuannya sendiri, menumbuhkembangkan keterampilan yang lebih tinggi dan inkuiri, memandirikan siswa, dan meningkatkan kepercayaan diri sendiri (Arends, 2007). Pembelajaran PBL dapat mengarahkan siswa untuk menggunakan pengetahuannya dalam memecahkan masalah didunia nyata dengan merefleksikan temuan yang dipelajari (Hmelo-Silver, 2004), dapat merangsang siswa mengidentifikasi permasalahan dan pemecahannya secara multidisiplin dalam kerja tim, serta dapat meningkatkan literasi saintifik siswa (Suwono et al., 2015). Pemanfaatan potensi siswa sebagai individu maupun sebagai anggota kelompok dalam mengidentifikasi permasalahan maupun merumuskan penyelesaiannya memungkinkan siswa untuk mengeksplorasi berbagai disiplin ilmu dalam permasalahan keanekaragaman hayati. PBL bagi guru juga merupakan sarana untuk memahami permasalahan dengan disiplin ilmu yang dikuasai, mengembangkan pembelajaran kolaboratif serta menumbuhkan keterampilan belajar sepanjang hayat (Simone, Lussier, \& Hall, 2014).

Metode membaca yang tepat diharapkan dapat membantu siswa dalam memahami konteks bahan bacaan dari berbagai sumber sehingga dapat membantu siswa untuk meningkatkan literasi sains. Salah satu metode membaca yang dapat dikembangkan dalam proses pembelajaran adalah SQ3R (Survey, Question, Read, Review, Recite) yang merupakan strategi membaca untuk membantu siswa meningkatkan pemahaman, memori, dan efisiensi dalam membaca (Robinson, 1970) sehingga dapat diintegrasikan dalam proses pembelajaran untuk mengembangkan kebiasaan membaca yang efektif. Metode ini dapat meningkatkan pencapaian siswa terhadap kemampuan membaca dan penguasaan kosakata (Soma, Mukminin, \& Noprival, 2015), mendukung pelaksanaan pembelajaran kooperatif jigsaw (Li, Fan, Huang, \& Chen, 2013) dan meningkatkan kualitas pembelajaran sains (Jamiludin, Jumatin, Darnawati, \& Uke, 2017). Bahan bacaan dalam pembelajaran yang mengintegrasi metode membaca dalam pembelajaran Biologi dapat berasal dari artikel ilmiah, berita aktual informasi ilmiah maupun isu lingkungan terkini. Bahan ajar sebagai suatu bacaan merupakan materi yang disusun sistematis untuk membantu guru dalam kegiatan belajar bersama siswa (Direktorat Pembinaan SMA, 2010). Pembelajaran dengan menggunakan bahan ajar yang tepat sesuai dengan tujuan pembelajaran dapat meningkatkan prestasi akademik siswa (Awolaju, 2015) termasuk kemampuan kognitif dalam literasi sains dan kemampuan afektif dalam sikap peduli lingkungan. Bahan ajar yang sesuai dengan perkembangan kognitif siswa, terstruktur, lengkap dan sistimatis sehingga dapat diintegrasikan dengan model pembelajaran yang dibutuhkan adalah modul. Modul memiliki karakteristik self instructional, self contained, stand alone, adaptive dan user friendly (Departemen Pendidikan Nasional, 2008) sehingga sangat cocok digunakan oleh siswa secara mandiri dalam mencapai kompetensi yang diharapkan.

Materi keanekaragaman hayati merupakan materi yang berisi tentang tingkat keanekaragaman hayati, keanekaragaman hayati Indonesia, dampak aktivitas manusia terhadap keanekaragaman hayati dan upaya pelestariannya. Materi ini sangat strategis untuk memberikan wawasan kepedulian terhadap lingkungan terutama aspek konservasi dan pengelolaan sumber daya alam. Pembelajaran keanekaragaman hayati biasanya berpusat pada materi yang telah terdapat dalam buku teks dan kurang dapat menampilkan kekayaan keanekaragaman hayati Indonesia, dampak kegiatan manusia yang memengaruhi dinamikanya serta upaya pelestarian yang perlu dilakukan. Penerapan pembelajaran model PBL dengan SQ3R pada materi ini diharapkan siswa dapat membangun kemampuan literasi sains sekaligus dapat memotivasi siswa untuk berperan aktif dalam upaya konservasi dimasa sekarang maupun dimasa depan sebagai bentuk sikap peduli lingkungan.

\section{METODE}

Metode penelitian ini menggunakan quasi eksperimen nonrandomized control group pretest-posttest design dengan skema rancangan pada tabel 1 .

\section{Tabel 1. Desain Penelitian}

\begin{tabular}{lccc}
\hline \multicolumn{1}{c}{ Kelas } & Pretest & Perlakuan & Postest \\
\hline PBL-SQ3R dengan modul (Eksperimen) & O1 & Tx1 & O2 \\
\hline PBL-SQ3R tanpa modul (Kontrol potitif) & O3 & Tx2 & O4 \\
\hline Penugasan-Diskusi-Presentasi (Kontrol negatif) & O5 & - & O6 \\
\hline
\end{tabular}

Keterangan:

Tx1 = Kegiatan pembelajaran PBL-SQ3R dengan modul

Tx1 = Kegiatan pembelajaran PBL-SQ3R tanpa modul

O1 = Pretest pada kelas PBL-SQ3R dengan modul

$\mathrm{O} 2$ = Postest pada kelas PBL-SQ3R dengan modul

$\mathrm{O} 3$ = Pretest pada kelas PBL-SQ3R tanpa modul 
$\mathrm{O} 4=$ Postest pada kelas PBL-SQ3R tanpa modul

O5 = Postest pada kelas konvensional

O6 = Pretest pada kelas konvensional

Penelitian ini dilaksanakan selama dua bulan, yaitu bulan Oktober-November 2018. Populasi dari penelitian ini adalah siswa kelas X IPA di SMA Negeri 8 Kediri sebanyak lima kelas, sedangkan sampelnya adalah tiga kelas, yaitu kelas eksperimen, kontrol positif, dan kontrol negatif. Pengumpulan data kemampuan literasi sains dan sikap peduli lingkungan dilakukan dengan memberikan pretes sebelum proses pembelajaran dilakukan dan postes sesudah proses pembelajaran selesai dilakukan. Keseluruhan proses pembelajaran dilakukan sebanyak enam kali pertemuan.

\section{HASIL}

Hasil penelitian ini berupa nilai pretes-postes literasi sains dan sikap peduli lingkungan dianalisis dengan perhitungan statistik Anacova. Keseluruhan hasil penelitian ini adalah sebagai berikut.

\section{Literasi Sains}

Data nilai literasi sains pada semua kelas yang diteliti mengalami kenaikan rata-rata nilai. Kelas PBL-SQ3R dengan modul naik sebanyak 30,42; kelas PBL-SQ3R tanpa modul naik sebanyak 25,51 dan kelas kontrol naik sebanyak 11,52. Rerata tersebut menunjukkan bahwa meskipun semua kelas menunjukkan kenaikan, namun kelas PBL-SQ3R dengan modul mengalami kenaikan yang paling tinggi yaitu 30,42. Keseluruhan rerata nilai pretes dan postes dapat dilihat pada gambar 1 . Hasil analisis statistik anacova dengan SPSS dapat dilihat pada tabel 2.

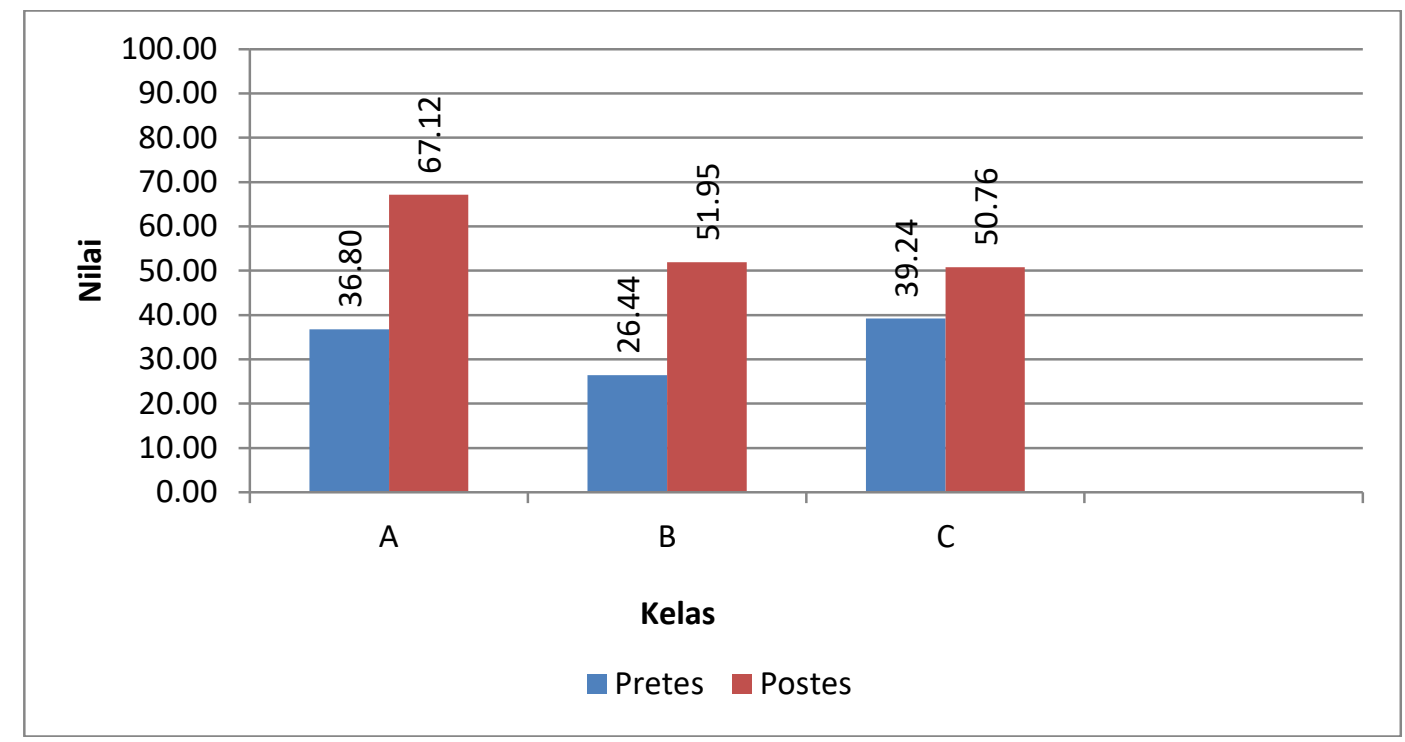

Gambar 1. Rekapitulasi Rerata Nilai Literasi Sains

Keterangan:

$\mathrm{A}=\mathrm{PBL}-\mathrm{SQ} 3 \mathrm{R}$ dengan Modul

$\mathrm{B}=\mathrm{PBL}-\mathrm{SQ} 3 \mathrm{R}$ tanpa Modul

$\mathrm{C}=$ Penugasan-Diskusi-Presentasi 
Tabel 2. Hasil Analisis Statistik Anacova dengan SPSS

\begin{tabular}{|l|r|r|r|r|r|}
\hline Source & Type III Sum of Squares & df & Mean Square & \multicolumn{1}{|c|}{ F } & Sig. \\
\hline Corrected Model & $6492.880^{\mathrm{a}}$ & 3 & 2164.293 & 17.984 & .000 \\
Intercept & 33745.573 & 1 & 33745.573 & 280.409 & .000 \\
Pretes & 1000.081 & 1 & 1000.081 & 8.310 & .005 \\
Kelas & 5147.812 & 2 & 2573.906 & 21.388 & .000 \\
Error & 11071.661 & 92 & 120.344 & & \\
Total & 328702.932 & 96 & & & \\
Corrected Total & 17564.541 & 95 & & & \\
\hline
\end{tabular}

a. $\mathrm{R}$ Squared $=.370$ (Adjusted R Squared $=.349$ )

Berdasarkan tabel data signifikansi kovariat pretes adalah 0,005 yaitu kurang dari 0,05 maka Ho ditolak. Dengan demikian, ada hubungan linier antara nilai pretes dan hasil postes literasi sains yang diperoleh siswa. Nilai signifikansi kelas sebesar 0,000 yaitu kurang dari 0,05 maka Ho ditolak, dengan demikian tanpa pretes ada pengaruh antara kelas perlakuan dengan nilai postes literasi sains yang diperoleh. Corrected Model nilai signifikansi 0,000, dibawah 0,05 maka Ho ditolak, dengan demikian secara bersama-sama ada perbedaan kelas perlakuan dan pretes yang memengaruhi hasil postes literasi sains. $\mathrm{R}$ squared 0,370 artinya hanya 37 persen dari hasil postes literasi sains yang berpengaruh dan ada variabel lain yang berpengaruh selain variabel yang terdapat dalam penelitian ini. Kesimpulannya adalah kelas perlakuan dan pretes memengaruhi hasil postes literasi sains, tetapi terdapat faktor lain yang berpengaruh terhadap hasil tersebut.

\section{Sikap Peduli Lingkungan}

Data nilai literasi sains terdiri atas nilai pretes dan postes. Keseluruhan hasil pretes dan postes terdapat pada gambar 2. Berdasarkan gambar 2 dapat diketahui bahwa pada semua kelas yang digunakan dalam penelitian mengalami kenaikan rata-rata nilai sikap peduli lingkungan yaitu kelas PBL-SQ3R dengan modul naik sebanyak 8,04; kelas PBL-SQ3R tanpa modul naik sebanyak 7,26 dan kelas kontrol naik sebanyak 3,77. Rerata tersebut menunjukkan bahwa meskipun semua kelas menunjukkan kenaikan, namun kelas PBL-SQ3R dengan modul mengalami kenaikan yang paling tinggi yaitu 8,04. Hasil analisis statistik anacova dengan SPSS dapat dilihat pada tabel 3.

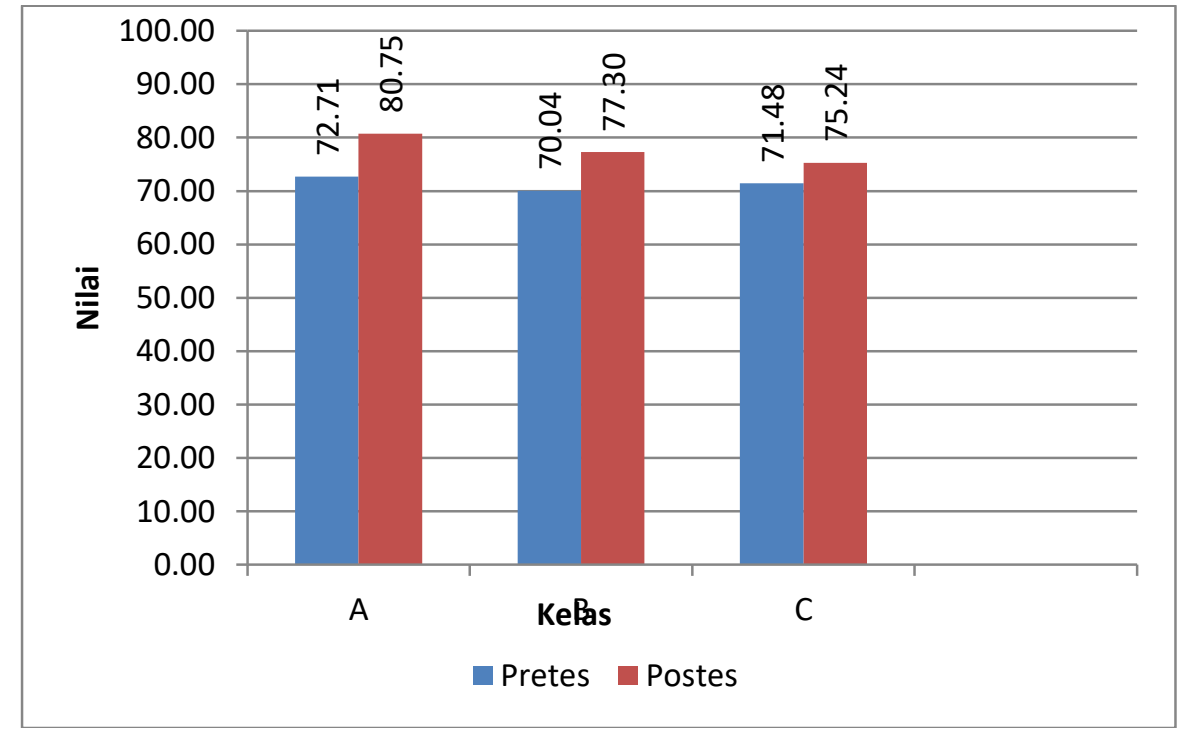

Gambar 2. Rekapitulasi Rerata Nilai Sikap Peduli Lingkungan

Keterangan:

$\mathrm{A}=$ PBL-SQ3R dengan Modul

$\mathrm{B}=\mathrm{PBL}-\mathrm{SQ} 3 \mathrm{R}$ tanpa Modul

$\mathrm{C}=$ Penugasan-Diskusi-Presentasi 
Tabel 3. Hasil Analisis Statistik Anacova dengan SPSS

\begin{tabular}{|l|r|r|r|c|c|}
\hline Source & Type III Sum of Squares & df & Mean Square & F & Sig. \\
\hline Corrected Model & $1212.410^{\mathrm{a}}$ & 3 & 404.137 & 44.812 & .000 \\
Intercept & 873.646 & 1 & 873.646 & 96.872 & .000 \\
Pretes & 699.503 & 1 & 699.503 & 77.563 & .000 \\
Kelas & 390.400 & 2 & 195.200 & 21.644 & .000 \\
Error & 829.704 & 92 & 9.019 & & \\
Total & 583643.914 & 96 & & & \\
Corrected Total & 2042.114 & 95 & & & \\
\hline
\end{tabular}

a. $\mathrm{R}$ Squared $=.594$ (Adjusted R Squared $=.580$ )

Berdasarkan tabel 3 data signifikansi kovariat pretes adalah 0,000 yaitu kurang dari 0,05 maka Ho ditolak, dengan demikian ada hubungan linier antara nilai pretes dan hasil postes sikap peduli lingkungan yang diperoleh siswa. Nilai signifikansi kelas sebesar 0,000 yaitu kurang dari 0,05 maka Ho ditolak. Dengan demikian, tanpa pretes ada pengaruh antara kelas perlakuan dengan nilai postes sikap peduli lingkungan yang diperoleh. Corrected Model nilai signifikansi 0,000, dibawah 0,05 maka Ho ditolak. Dengan demikian, secara bersama-sama ada perbedaan kelas perlakuan dan pretes yang memengaruhi hasil postes sikap peduli lingkungan. R squared 0,594 artinya hanya 59 persen dari hasil postes sikap peduli lingkungan yang berpengaruh selain variabel yang terdapat dalam penelitian ini. Kesimpulannya adalah kelas perlakuan dan pretes memengaruhi hasil postes sikap peduli lingkungan, tetapi terdapat faktor lain yang berpengaruh terhadap hasil tersebut.

\section{PEMBAHASAN}

Modul sebagai salah satu bentuk bahan ajar disusun untuk digunakan bersama oleh siswa dan guru dalam kegiatan pembelajaran. Modul yang baik dapat membantu siswa mempelajari materi dengan baik karena disusun secara sistematis menjelaskan tujuan yang ingin dicapai, memotivasi siswa untuk belajar, mengantisipasi kesukaran siswa dan berpusat pada siswa sebagai pembelajar mandiri (Pannen \& Purwanto, 2001). Penggunaan modul secara sistematis dapat memudahkan siswa dalam mengikuti pembelajaran dan mengerjakan tugas yang terkait dengan materi pembelajaran. Siswa juga dapat mempelajari modul secara mandiri baik secara individu maupun secara berkelompok didalam maupun diluar jam tatap muka di sekolah. Hasil penelitian menyatakan bahwa pembelajaran Biologi dengan menggunakan modul lebih baik dalam memperhatikan kemampuan siswa sehingga guru dapat memberikan bantuan individual yang diperlukan (Ali, Faitma, Khan, Hussain, \& Ghazi, 2014).

Problem Based Learning sebagai model pembelajaran berdasarkan teori konstruktivisme dimana pembelajaran berpusat pada siswa (student centered) untuk mengembangkan kemampuan belajar, berpartisipasi aktif dalam pembelajaran untuk membangun pengetahuannya secara mandiri. Pandangan kognitif-konstruktivis menyatakan bahwa pada usia berapapun siswa dapat aktif terlibat dalam proses mencari serta memperoleh informasi dan membangun pengetahuannya sendiri karena ilmu pengetahuan bersifat dinamis dan siswa akan selalu mengalami pengalaman baru yang terus memodifikasi pengetahuan awal (Arends, 2007). Siswa memiliki tingkat perkembangan aktual (memiliki kemampuan untuk mempelajari sesuatu secara mandiri) dan potensial (kemampuan untuk melakukan sesuatu dengan bantuan orang lain) (Vigotsky, 2010). Lebih lanjut dikemukakan bahwa diantara tingkat perkembangan aktual dan potensial terdapat Zone of Proximal Development (ZPD) yaitu aspek sosial pembelajaran dimana interaksi sosial dapat memacu timbulnya gagasan baru untuk meningkatkan perkembangan intelektual siswa. PBL dapat dimulai dengan memberikan acuan permasalahan dari berbagai sumber, misalnya siswa diberikan kesempatan untuk langsung mengamati kehidupan di sekitarnya, melalui video pembelajaran, maupun bahan bacaan. Pembelajaran PBL-SQ3R memadukan keterampilan siswa memahami permasalahan dengan meningkatkan kemampuan membaca menggunakan metode SQ3R. Metode SQ3R dalam modul digunakan untuk memahami artikel penelitian sebagai bahan bacaan pada tahap Orientasi pada Masalah model pembelajaran PBL.

Penerapan PBL dalam pembelajaran dapat meningkatkan literasi membaca siswa (Pamungkas, Probosari, \& Puspitasari, 2015). Peningkatan literasi membaca diharapkan dapat meningkatkan minat siswa dalam memahami hal-hal baru dari berbagai sumber. Sumber yang beragam dapat memperluas wawasan siswa untuk mengenal, menerapkan dan mengevaluasi pengetahuan yang berkaitan dengan sains sehingga literasi sains siswa dapat meningkat. Pembelajaran dengan menggunakan modul keanekaragaman hayati berbasis PBL-SQ3R memberikan pengalaman belajar bagi siswa dalam berlatih membaca dan mengarahkan siswa untuk menyelesaikan permasalahan disekitarnya terutama yang berkaitan dengan keanekaragaman hayati. Bahan ajar yang baik dan metode penyampaian yang tepat akan meningkatkan pemahaman terhadap materi pelajaran sehingga berperan penting pada prestasi akademik siswa di bidang biologi (Effiong \& Igiri, 2015). 
Peningkatan literasi sains berkaitan dengan pengembangan kemampuan kreatif dalam memanfaatkan pengetahuan dan keterampilan ilmiah berdasarkan bukti yang tepat untuk memecahkan permasalahan sehari-hari (Holbrook \& Rannikmae, 2009). Model pembelajaran PBL mengarahkan siswa untuk mengembangkan kemampuan secara bertahap dalam mengenali permasalahan, mendiskusikan desain penyelidikan ilmiah, mencari informasi tentang permasalahan yang ditemukan serta merumuskan solusi. Keseluruhan proses tersebut memerlukan keterampilan mencari informasi yang tepat dari sumber awal yaitu artikel penelitian pada modul. Berdasarkan pencapaian pada kelas PBL-SQ3R menggunakan modul semua indikator literasi sains meningkat bila dibandingkan dengan kelas PBL-SQ3R tanpa modul dan kelas kontrol negatif yang menggunakan pembelajaran diskusi penugasan. Hal ini sejalan dengan penelitian (Boscardin et al., 2010) bahwa integrasi membaca dan penyelidikan ilmiah meningkatkan kualitas pembelajaran literasi sains, penyelidikan metakognisi, pemahaman bacaan dan pembelajaran kolaboratif. Pembelajaran sains menggunakan model pembelajaran berbasis masalah dapat meningkatkan literasi sains (Ardianto \& Rubini, 2016). Penerapan pembelajaran berbasis masalah secara aktif dapat memengaruhi prestasi akademik siswa dan pemahaman konsep (Akinoglu \& Tandogan, 2007). Literasi sains penting bagi masyarakat dalam menyelesaikan permasalahan yang terkait dengan sains dan teknologi yang meliputi keterampilan proses sains dasar dan keterampilan proses sains terintegrasi (Turiman, Omar, Daud, \& Osman, 2012). Potensi implikasi pengetahuan masyarakat yang mampu dikenal dan diiden-tifikasi oleh siswa diharapkan mampu mengembangkan keterampilan siswa sekaligus dapat membantu memberikan kontribusi bagi peran sains dalam kehidupan sehari-hari.

Sikap merupakan kecenderungan untuk merespos suatu objek, situasi maupun konsep tertentu (Sunarti \& Rahmawati, 2014) terdiri atas tiga komponen yang saling menunjang yaitu komponen kognitif yaitu representasi kepercayaan tertentu, komponen afektif yaitu perasaan atau aspek emosional dan komponen konatif yang nerupakan kecenderungan berperilaku (Azwar, 1995). Lebih lanjut dikemukakan bahwa pembentukan sikap manusia dapat dipengaruhi oleh pengalaman pribadi, pengaruh orang lain, kebudayaan, media massa, faktor emosional, dan lembaga pendidikan.

Pembentukan sikap melalui lembaga pendidikan dapat dilakukan melalui proses pembelajaran yang ditujukan untuk membentuk sikap tertentu salah satunya sikap peduli lingkungan. Sikap peduli lingkungan merupakan salah satu komponen pendidikan karakter untuk mencegah kerusakan lingkungan dan berupaya memperbaiki kerusakan lingkungan yang sudah terjadi (Balitbang, 2010). Pembelajaran biologi pada materi keanekaragaman hayati sangat potensial untuk membangun dan meningkatkan sikap peduli lingkungan terutama yang berkaitan dengan aktivitas manusia. Aktivitas manusia merupakan penyebab utama kerusakan lingkungan mulai dari pencemaran, permasalahan sampah, eksploitasi sumber daya alam hingga penangkapan satwa liar untuk diperdagangkan. Pembelajaran keanekaragaman hayati seharusnya berfokus pada pembelajaran yang bermakna sehingga tidak hanya mengarah pada pemahaman konsep, tetapi juga sebagai upaya untuk melestarikannya. Pendekatan pembelajaran dengan menganalisis dari berbagai sudut pandang dapat membantu siswa untuk berpikir kritis tentang perlindungan keanekaragaman hayati dan perlindungannya (Navarro-Perez \& Tidball, 2012). Lebih lanjut dikemukakan bahwa keterampilan ini akan membantu siswa menyadari potensi tindakan mereka sehingga terbentuk kepedulian terhadap alam.

Secara umum, diperlukan perubahan paradigma penyusunan desain pembelajaran untuk mencapai tujuan pendidikan afektif kepedulian terhadap lingkungan dengan menggunakan instrumen dan metode pembelajaran yang tepat (Mamat \& Mokhtar, 2012). Pembelajaran berbasis masalah akan secara tidak langsung memengaruhi sikap siswa dalam menghasilkan solusi permasalahan lingkungan yang terjadi di sekitarnya (Mardiana, Irawati, \& Sueb, 2016). Pembelajaran untuk meningkatkan sikap peduli lingkungan dapat dilakukan dengan berbagai cara yang didukung secara langsung oleh sekolah. Hasil penelitian (Le Hebel, Montpied, \& Fontanieu, 2014) menyatakan bahwa sekolah dapat meningkatkan apresiasi terhadap alam dan kesadaran tentang lingkungan sehingga siswa dapat meningkatkan dukungannya terhadap pelestarian lingkungan dalam bentuk kegiatan ekstrakurikuler. Kegiatan pembelajaran yang terkait langsung dengan kegiatan tersebut dapat menjadi sarana pendukung bagi guru biologi dalam mengembangkan sikap peduli lingkungan pada siswa secara terus menerus dan berkelanjutan sehingga dapat membentuk kesadaran siswa pada saat ini maupun pada masa mendatang.

\section{SIMPULAN}

Implementasi pembelajaran dengan menggunakan modul dapat meningkatkan rerata nilai postes literasi sains dan sikap peduli lingkungan pada materi keanekaragaman hayati siswa kelas X IPA SMA Negeri 8 Kediri. Penerapan penggunaan modul pada kalangan sejawat guru Biologi diperlukan untuk menambah wawasan, saran pengembangan dan respons siswa yang beragam, misalnya dengan diterapkan pada siswa di sekolah yang lain dalam forum ilmiah guru. Pengembangan modul lebih lanjut bekerjasama dengan pihak lain yang bergerak di bidang konservasi lingkungan dan keanekaragaman hayati Indonesia sangat diperlukan untuk meningkatkan kesadaran siswa berperan aktif melestarikan keanekaragaman hayati. 


\section{DAFTAR RUJUKAN}

Akinoglu, O., \& Tandogan, R. O. (2007). The Effects of Problem-Based Active Learning in Science Education on Students' Academic Achievement, Attitude and Concept Learning. Eurasia Journal of Mathematics, Science \& Technology Education, 3(1), 71-81.

Ali, R., Faitma, Z. T., Khan, M. S., Hussain, S., \& Ghazi, S. R. (2014). Effectiveness of Modular Teaching in Biology at Secondary Level. Asian Social Science, 6(9). https://doi.org/10.5539/ass.v6n9p49

Ardianto, D., \& Rubini, B. (2016). Comparison of Students' Scientific Literacy in Integrated Science Learning through Model of Guided Discovery and Problem Based Learning. Jurnal Pendidikan IPA Indonesia, 5(1), 31-37. https://doi.org/10.15294/jpii.v5i1.5786

Arends, R. I. (2007). Learning to Teach. New York: The McGraw-Hill Campanies.

Awolaju, B. A. (2015). Instructional Materials as Correlates of Students' Academic Performance in Biology in Senior Secondary Schools in Osun State. International Journal of Information and Education Technology, 6(9), 705-708. https://doi.org/10.7763/ijiet.2016.v6.778

Boscardin, C. K., Hanson, T. L., Schneider, S. A., Herman, J., Jones, B., Madden, S., ... Litman, C. (2010). Integrating Literacy and Science in Biology: Teaching and Learning Impacts of Reading Apprenticeship Professional Development. American Educational Research Journal, 48(3), 647-717. https://doi.org/10.3102/0002831210384839

Effiong, O. E., \& Igiri, C. E. (2015). Impact of Instructional Materials in Teaching and Learning of Biology in Senior Secondary Schools in Yakurr LG A. International Letters of Social and Humanistic Sciences, 62, 27-33. https://doi.org/10.18052/www.scipress.com/ilshs.62.27

Hmelo-Silver, C. E. (2004). Problem-Based Learning: What and How Do Students Learn? Educational Psychology Review, $16(3), 235-264$.

Holbrook, J., \& Rannikmae, M. (2009). The Meaning of Scientific Literacy. International Journal of Environmental \& Science Education, 4(3), 275-288.

Jamiludin., Jumatin., Darnawati., \& Uke, W. A. S. (2017). The Use of SQ3R Method in Improving Quality and Result of Social Sciences Learning in XI Grade SMAN 3 Kendari Southeast Sulawesi Indonesia. Proceedings of the 3rd International Conference on Education and Training, 128, 208-212.

Le Hebel, F., Montpied, P., \& Fontanieu, V. (2014). What Can Influence Students' Environmental Attitudes? Results from a Study Of 15-Year-Old Students in France. International Journal of Environmental and Science Education, 9(3), 329-345. https://doi.org/10.12973/ijese.2014.218a

Li, L. Y., Fan, C. Y., Huang, D. W., \& Chen, G. D. (2013). The Effects of the E-book System with the Reading Guidance and the Annotation Map on the Reading Performance of College Students. Educational Technology and Society, 17(1), 320331.

Mamat, M. N., \& Mokhtar, F. (2012). Environmental Attitude Profile among Muslim Students of Environmental Course in Malaysia. Procedia - Social and Behavioral Sciences, 42, 92-99. https://doi.org/10.1016/j.sbspro.2012.04.170

Mardiana., Irawati, M. H., \& Sueb. (2016). Pembelajaran Berbasis Masalah (Problem Based Learning) sebagai Upaya Meningkatkan Hasil Belajar Kognitif dan Sikap Peduli Lingkungan Problem Based Learning (PBL) As An Effort to Improve Cognitive Learning Outcomes and Environmental Cares Attitude. In Prosiding Seminar Nasional II Tahun 2016, Kerjasama Prodi Pendidikan Biologi FKIP dengan Pusat Studi Lingkungan dan Kependudukan (PSLK) Universitas Muhammadiyah Malang Malang (pp. 156-167).

Navarro-Perez, M., \& Tidball, K. G. (2012). Challenges of Biodiversity Education : A Review of Education Strategies for Biodiversity Education. International Electronic Journal of Environmental Educationfile:///C:/Users/rachel/Desktop/questirre/international Organizzations.pdf, 2(1), 12-30.

NCREL and the Metiri Group. (2003). enGauge 21st Century Skills for 21 st Century Learners: Literacy in the Digital Age. https://doi.org/10.1111/j.1467-8535.2006.00602_10.x

OECD Publishing. (2012). PISA 2012 Assessment and Analytical Framework PISA 2012 Assessment and Analytical Framework.

OECD Publishing. (2016). PISA 2015 Assessment and Analytical Framework: Science, Reading, Mathematic and Financial Literacy,. OECD Publishing. https://doi.org/10.1787/9789264255425-en

Pamungkas, R., Probosari, R. M., \& Puspitasari, D. (2015). Peningkatan Literasi Membaca melalui Penerapan Problem Based Learning pada Pembelajaran Biologi Siswa Kelas X MIA1 SMAN 1 Boyolali. In Seminar Nasional Pendidikan Sains Magister Pendidikan Sains dan Doktor Pendidikan IPA FKIP UNS (pp. 406-412).

Pannen, P., \& Purwanto. (2001). Penulisan-Bahan-Ajar. Depdiknas.

Simone, C. De, Lussier, J., \& Hall, L. (2014). Problem-Based Learning in Teacher Education : Trajectories of Change Faculty of Education, 4(12), 17-29. 
Soma, R., Mukminin, A., \& Noprival. (2015). Toward a Better Preparation of Student Teachers’ Reading Skill : The SQ3R Strategy with Authentic and Simplified Texts on Reading Literacy and Vocabulary Mastery. Journal of Education and Learning, 9(2), 125-134.

Sunarti., \& Rahmawati, S. (2014). Penilaian dalam Kurikulum 2013. Yogyakarta: Andi Offset.

Suwono, H., Rizkita, L., \& Susilo, H. (2015). Peningkatan Literasi Saintifik Siswa SMA melalui Pembelajaran Biologi Berbasis Masalah Sosiosains. Jurnal Ilmu Pendidikan, 21(2), 136-144.

Thoharudin, U., Hendrawati, S., \& Rustaman, A. (2011). Membangun Literasi Sains Siswa. Bandung: Humaniora.

Turiman, P., Omar, J., Daud, A. M., \& Osman, K. (2012). Fostering the 21st Century Skills through Scientific Literacy and Science Process Skills. Procedia - Social and Behavioral Sciences, 59, 110-116.

https://doi.org/10.1016/j.sbspro.2012.09.253 